\title{
Effect Comparison of the Teaching Method Based on Occupation Ability of Higher Vocational School
}

\author{
Huiling Zhao \\ Zhejiang Industry \&Trade Vocational college, Wenzhou, Zhejiang \\ 26000690@qq.com
}

\begin{abstract}
The Vocational School teaching methods is directly related to the students' vocational ability. However, the traditional teaching model is very insufficient. Based on the investigation about students, we actively change the teaching idea and update the teaching methods and pay more attention to the initiative and enthusiasm of students in teaching. we achieved certain effect from the teaching methods reform.

Index Terms - higher vocational education, vocational ability, teaching method

\section{Introduction}

In 2011, some opinions on the promotion of higher vocational education reform and innovation to lead the development of vocational education in science by Ministry of Education points out: the main task of higher vocational education is to cultivate high-end talents in the forefront of production, construction, management and service. Thus, higher vocational education should focus on the cultivation of occupation ability. The occupation ability refers to the personal skills for professional activities which integrates knowledge, skills, attitude and physical ability. The occupation ability is the basic work ability for professional situations, which includes: Understanding and communication ability, thinking ability, management ability, analysis ability and practical ability.
\end{abstract}

\section{The Teaching Effect Before Reform Of Higher Vocational School}

Training of professional ability should be throughout the whole teaching process, thus, the teaching method is particularly important.. In recent years, the total number of technical staff team is increasing. Though

There are millions of skilled talents in China every year, it is difficult to meet the actual requirement of the employer. Because they has a widespread drawback, such as poor hands, narrow professional, weak analysis of the problem and critical thinking, lack of ability and experience to solve practical problems[1]. Our school has the same question. The survey of 2009 graduates showed that the overall satisfaction of basic work ability is $70 \%$, the creative ability of students is only $60 \%$, and the satisfaction of core knowledge is $68 \%$. $8 \%$ graduates thought the problem in teaching is student participation in class is not enough, $27 \%$ said the teaching method can't arouse the interest in learning, learning and practice is not enough for $38 \%$. The reason is that there is a certain lack of teaching methods. Several years ago, the teaching mode is the straight-line whose center is teacher, class and textbook. Teacher served as the main role of the class, which emphasized on teaching process while neglecting students learning process. Teacher is not good at questioning his students and guiding students to think and discover problems. Students are also cynicism in learning process, they are not accustomed to answer and ask, not to mention the challenges the authority of a teacher. In this mode, students is in a relatively passive acceptance of knowledge, which is not conductive to stimulate students skepticism and not conductive to cultivate the exploration and innovation capability. To solve these problems, our school made great efforts for teaching reform in recent years. We increased the proportion of task-driving teaching method and operation teaching method for better learning effect.

\section{Reform Of Teaching Method Of Vocational School}

In order to make the teaching reform more in line with the characteristics of higher vocational students, we conducted a survey on the teaching method satisfaction about 600 students, the results are as follows:

TABLE1: Identity Degree Of Teaching Method

\begin{tabular}{|l|l|l|l|l|l|l|l|}
\hline grade & $\begin{array}{l}\text { TeachingMethod } \\
(\%)\end{array}$ & $\begin{array}{l}\text { Research method } \\
(\%)\end{array}$ & $\begin{array}{l}\text { Case teaching method } \\
(\%)\end{array}$ & $\begin{array}{l}\text { Heuristic teaching } \\
(\%)\end{array}$ & $\begin{array}{l}\text { Interactive teaching } \\
(\%)\end{array}$ & $\begin{array}{l}\text { Operation teaching } \\
(\%)\end{array}$ & $\begin{array}{l}\text { Task-driven teaching } \\
(\%)\end{array}$ \\
\hline Freshmen & 16.2 & 15.6 & 15 & 16.8 & 17.2 & 8 & 11.2 \\
\hline sophomore & 14.2 & 13.8 & 16 & 17.8 & 17.6 & 8.6 & 12 \\
\hline Junior & 12.7 & 12.9 & 14.7 & 17.8 & 17.8 & 10.7 & 13.4 \\
\hline
\end{tabular}

We drew a conclusion from the chart that more and more students agreed with the teaching mode which has good interaction between teacher and student, such as research method, heuristic teaching and interactive teaching. In the continuous part-time, social practice and exercitation, sophomore and junior wanted teaching methods that can enhance their professional competence. That is why the proportion of operation method increased from $8 \%$ to $10.7 \%$, and task-driven teaching increased from $11.2 \%$ to $13.4 \%$. The survey showed that students clearly realized the importance of enhancing the occupation ability especially learning ability. Thus they showed increasing interested in teaching methods to cultivate self-learning. 
Based on the investigation, our school focused on the cultivation of students' vocational ability for future job requirements.(i) The teaching method reform direction: the reform idea should take occupation ability development as the core and the work process as the object, emphasizing the exchanges between the education and the educated. Thus the subordinate status of students is changed form passive to active. This requires teachers pay more attention to the reality of the students and adopt the teaching methods that can cultivate the ability of analyzing and solving problem on one's own. (ii) The concrete ways of teaching reform method: the concept of vocational training with occupation education as the guidance and work task as the carrier and occupation ability training as the goal is widely accepted[2]. Therefore, the teaching mode integrated Teaching-Learning-doing is took in class. In this mode, we build the process about proposed task, students discuss, task implementation and teachers and students evaluation. Through the process, we strengthened the ideas of integrity of learning and practice and synchronization learning with assessment. In theory course teaching, we actively used heuristic teaching and interactive teaching to create a multilateral teaching environment through interpretation, question, and discussion. In the process of discussion, students keep the enthusiasm and interest, so as to realize the collision of different point of view and stimulate the activity and exploration of teachers and students. In practice course teaching, we keep trying operation teaching and task-driven teaching. In practice learning, driven by the operation and common task, students make autonomous and cooperative learning with the active application of leaning resources. In our school, we take students learning team as the center, combining the theory and practice. In team discussion, students can obtain the greatest idea through their mutual excitation, at the same time, they can form the correct values of competition and cooperation by increasing exchanges and cooperation. By adopting operation and task-driven teaching, teaching is changed from teaching knowledge to teaching how to solve problem and complete task. Compared with the traditional teaching method, the teaching focus on interaction between teachers and students is better for the cultivation of students' occupation ability.

Not only that, we emphasize the character development on the basis of students in common. According to the students' profession, we not only take different teaching method such as heuristic teaching, case teaching, object teaching and role playing, but also integrate them in teaching.

\section{Conclusion}

The reform of teaching method of our school is more effective. According to Mycos survey 2012(mycos survey refers to the social demand and training quality annual report of Zhejiang Industry \&Trade Vocational college, whose data investigation and index calculation is independently completed by Mycos team as a third party. Mycos is a professional third-party data consulting and quality assessment agencies in China with good credibility recognized by government, academia, business and the public. Mycos represents my Chinese occupation ability.), overall satisfaction of the basic work ability, innovation ability and core knowledge have different degrees improvement in 2011 graduates than 2010, which is shown as follows:

TABLE2: Satisfation of Professional Ability of 2010 and 2011 Graduates

\begin{tabular}{|l|c|c|c|}
\hline & 2010 graduates $(\%)$ & 2011 graduates $(\%)$ & 2011 graduates of our province $(\%)$ \\
\hline Overall Satisfaction of basic work ability & 70 & 79 & 80 \\
\hline Overall satisfaction of innovation ability & 60 & 79 & 80 \\
\hline Satisfaction of core knowledge & 68 & 78 & 78 \\
\hline
\end{tabular}

In addition to this, the positive study and scientific analysis has achieved $80 \%$ and $85 \%$ satisfaction.

The function of higher vocational education is to make every students have basic professional skills. The teaching method is the basis of improving students' vocational ability. Therefore, renewal education idea, accelerate the reform of teaching methods and try to flexible and varied teaching methods is needed to adapt the development of modern society.

\section{References}

[1] Ying Ji, "Study on research-oriented university curriculum system based on cultivation of engineering practice ability, "doctoral thesis, unpublished.

[2] Jianzhong Zha and Yongshan He, "The three strategic engineering education reform in China," Beijing Institute of Technology Press 2009, pp.25-40. 